\title{
An Assessment of Heavy-Metal Contamination in Soils within Auto-Mechanic Workshops Using Enrichment and Contamination Factors with Geoaccumulation Indexes
}

\author{
Isaac A. Ololade \\ Department of Chemistry and Industrial Chemistry, Adekunle Ajasin University, Akungba-Akoko, Nigeria \\ Email: olisa200@yahoo.com
}

Received 31 March 2014; revised 26 April 2014; accepted 16 May 2014

Copyright (C) 2014 by author and Scientific Research Publishing Inc. This work is licensed under the Creative Commons Attribution International License (CC BY). http://creativecommons.org/licenses/by/4.0/ (c) (i)

\section{Abstract}

Soil characterization and heavy metals in different layers $(0-15 \mathrm{~cm} ; 15-30 \mathrm{~cm}$ and $30-45 \mathrm{~cm}$ depth) of automobile mechanic waste dumps were studied. The soils showed remarkably high levels of all the metals above background concentrations with most $\mathrm{(Ni}, \mathrm{Cu}, \mathrm{Fe}, \mathrm{Cr}$ and $\mathrm{Cd})$ decreasing with soil depth. The distribution pattern were in the following order $\mathrm{Fe}>\mathrm{Cu}>\mathrm{Zn}>\mathrm{Pb}>\mathrm{Cr}>$ $\mathrm{Ni}>\mathrm{Cd}$. Across all the sampling locations and profiles, Fe and Cd showed the highest (476.4 $\left.\mu \mathrm{g} \cdot \mathrm{g}^{-1}\right)$ and least (37.5 $\left.\mu \mathrm{g} \cdot \mathrm{g}^{-1}\right)$ mean concentrations respectively. Pollution load index (PLI) and index of geoaccumulation $\left(I_{g e o}\right)$ revealed overall high and moderate contamination respectively but the enrichment factors (EFs) for $\mathrm{Pb} \mathrm{Ni}$ and $\mathrm{Cd}$ are severe. The inter-element relationship revealed the identical source of elements in the soils of the studied area. The accuracy of the results has been cheeked using the standard reference material; SRM (PACS-2). The mechanic waste dumps represent potential sources of heavy metal pollution to environment. The elevated levels of heavy metals in these soil profiles constitute a serious threat to both surface and groundwater.

\section{Keywords}

Heavy Metals, Soil Contamination, Soil Profiles, Automobile Mechanic, Enrichment Factor, Geoaccumulation Index 


\section{Introduction}

In Nigeria and most developing nations, increased automobile repairs/workshops activities are due to ever-increasing demand for personal vehicles, most of which are used "Tokunbo" vehicles. These have contributed markedly to the problem of soil contamination in most cities. Automobiles used (waste) oil contains oxidation products, sediments, water and metallic particles resulting from machinery wears, used batteries, organic and inorganic chemicals used in oil additives and metals [1]. Percolation of leachates from these materials poses threats to groundwater water. Unfortunately, information on the impact of automobile mechanics' activities on the ecosystem is still very rare.

The co-existence of toxic heavy metals and hydrocarbons (HCs) at many of the mechanics contaminated sites all over Nigeria and in other developing countries poses a severe threat to the environment. In fact, the significance of trace elements in soil chemistry is increasingly becoming an issue of global concern especially as soil constitutes a crucial component of rural and urban environment [2]-[4]. Heavy metals such as cadmium (Cd), copper $(\mathrm{Cu})$, chromium $(\mathrm{Cr})$, lead $(\mathrm{Pb})$, manganese $(\mathrm{Mn})$, nickel $(\mathrm{Ni})$ and zinc $(\mathrm{Zn})$ which are often contained as additives in some lubricants and gasoline are non-degradable in the soil. Some of them have been classified as priority pollutants by United State Environmental Protection Agency. At the moment, very few technologies, such as soil washing and bioremediation, are available to treat these mixed wastes [5].

High levels of heavy metals in soils do not necessarily reflect anthropogenic influence, but instead may be of a diagenetic origin [6] or grain size effects [7]. Since metals from both natural and anthropogenic sources accumulate in soils, it is often difficult to determine what fraction of soils metal load comes from which source. A crucial step for pollution assessment of soil is to establish the expected natural background concentration levels [8], from which various approaches can be used to quantify anthropogenic inputs.

A study of the distribution, enrichment and accumulation of heavy metals in soils within mechanic workshops is particularly important, especially in developing countries like Nigeria due to the unprofessional and lawless manner with which wastes are being disposed and to the assessment of the possible influence of anthropogenic activities on groundwater. In the present study, we carried out physicochemical characterization of soils from auto-mechanic workshops at different depths $(0-15 \mathrm{~cm} ; 15-30 \mathrm{~cm}, 30-45 \mathrm{~cm})$, namely pH, clay, silt, sand, total organic carbon (TOC), exchangeable cations, and equally examined the distribution of heavy metals such as $\mathrm{Pb}, \mathrm{Cr}, \mathrm{Cu}, \mathrm{Zn}, \mathrm{Fe}, \mathrm{Ni}$, and $\mathrm{Cd}$. Our assessment of soil contamination was based on degree of contamination using the enrichment factor $(\mathrm{EF})$, the geo-accumulation index $\left(I_{\text {geo }}\right)$ and the pollution load index [9]-[13]. In Nigeria, the pollution index represents the metal content effectively measured in soil by chemical analysis and the reference value of contamination obtained using a standard table formulated by the Department of Petroleum Resources of Nigeria, DPR [14] for maximum allowable concentration of heavy metals in soil (Table 1).

In addition, the standard employed for interpreting soil heavy contamination/pollution (C/P) varies from country to country based on chosen factors [15]

$$
\mathrm{C} / \mathrm{P} \text { value }=\frac{\text { Actual measurement of metal concentration in soil }}{\text { Target values from reference table }}
$$

The sampling site considered in this study (Ikare Akoko) is a major commercial city in Ondo State with well over 200 auto-mechanic workshops (big and small). After personal interview three locations were strategically considered due to the age of establishment, size and patronage. To date, there are scarce data pertaining to heavy

Table 1. Department of Petroleum Resources (DPR, 1991) target and intervention values for metals in soil.

\begin{tabular}{ccc}
\hline Metals & Target values $\left(\mu \mathrm{g} \cdot \mathrm{g}^{-1}\right)$ & $\begin{array}{c}\text { Intervention values } \\
\left(\mu \mathrm{g} \cdot \mathrm{g}^{-1}\right)\end{array}$ \\
\hline Cadmium & 0.8 & 17 \\
Chromium & 100.0 & 380 \\
Copper & 36.0 & 190 \\
Lead & 85.0 & 530 \\
Nickel & 35.0 & 210 \\
Zinc & 140.0 & 720 \\
\hline
\end{tabular}


metals composition of soil profiles (0 - $15 \mathrm{~cm}, 15$ - $30 \mathrm{~cm}$ and 30 - $45 \mathrm{~cm}$ depth) within and around auto-mechanic workshops in developing countries like Nigeria. Moreover, the available study has been limited to the top soil (0 - $15 \mathrm{~cm}$ depth) [3] [16] [17]. This is a major shortcoming considering the complex, porous nature of soil in retaining and releasing pollutants to groundwater [18]. The present study hopes to address some of these shortcomings. The ultimate aim of the study is to assess heavy metals status on soils around auto-mechanic workshops of this environment. Thus, the specific objectives include: 1) to study the vertical distribution of the various metals and 2) to assess the extent of anthropogenic contribution.

\section{Material and Methods}

\subsection{Study Area and Sampling}

This investigation was carried out within three auto-mechanic workshops in Ikare Akoko located in the northern geographical district of Ondo State, south-western part of Nigeria (Figure 1). Ikare is about $100 \mathrm{~km}$ from Akure, the Ondo State capital. Population as of 2006 was over 700,000. The temperature in Akoko land throughout the year ranges between $21^{\circ} \mathrm{C}-29^{\circ} \mathrm{C}$ and humidity is relatively high. The climate is tropical with approximately $20 \%$ precipitation. The workshops used in this study were chosen based on age of establishment and strategic location within the city. Two of the three workshops (approx. $10 \mathrm{~m}^{2}$ each in size) are located at a distance of about $250 \mathrm{~m}$ away from each other while the third workshop (approx. $15 \mathrm{~m}^{2}$ in size) is located south of the two other locations at a distance of almost $1200 \mathrm{~m}$ away. At each of the workshop investigated were three designated sites for soil sampling. Thus, three samples were collected separately at each site and at each depth and analyzed separately. The control (background) sample was obtained from a location remote from industrial zone and far removed from the influence of industrial activities at the University Campus, Akungba-Akoko, Ondo State. Sampling design for this study was based on two premises: first, the need to spread sample sites objectively over the study area and second, the need to ensure that site characteristics are adequately depicted. Soil samples were collected from three sampling depths $0-15 \mathrm{~cm}, 15-30 \mathrm{~cm}$ and $30-45 \mathrm{~cm}$, hereafter referred to as topsoil, subsoil and sub-sub soil respectively. The sampling was restricted to this zone because it provides the bulk of plant nutrients [19]. Samples were collected inside labeled polythene bags.

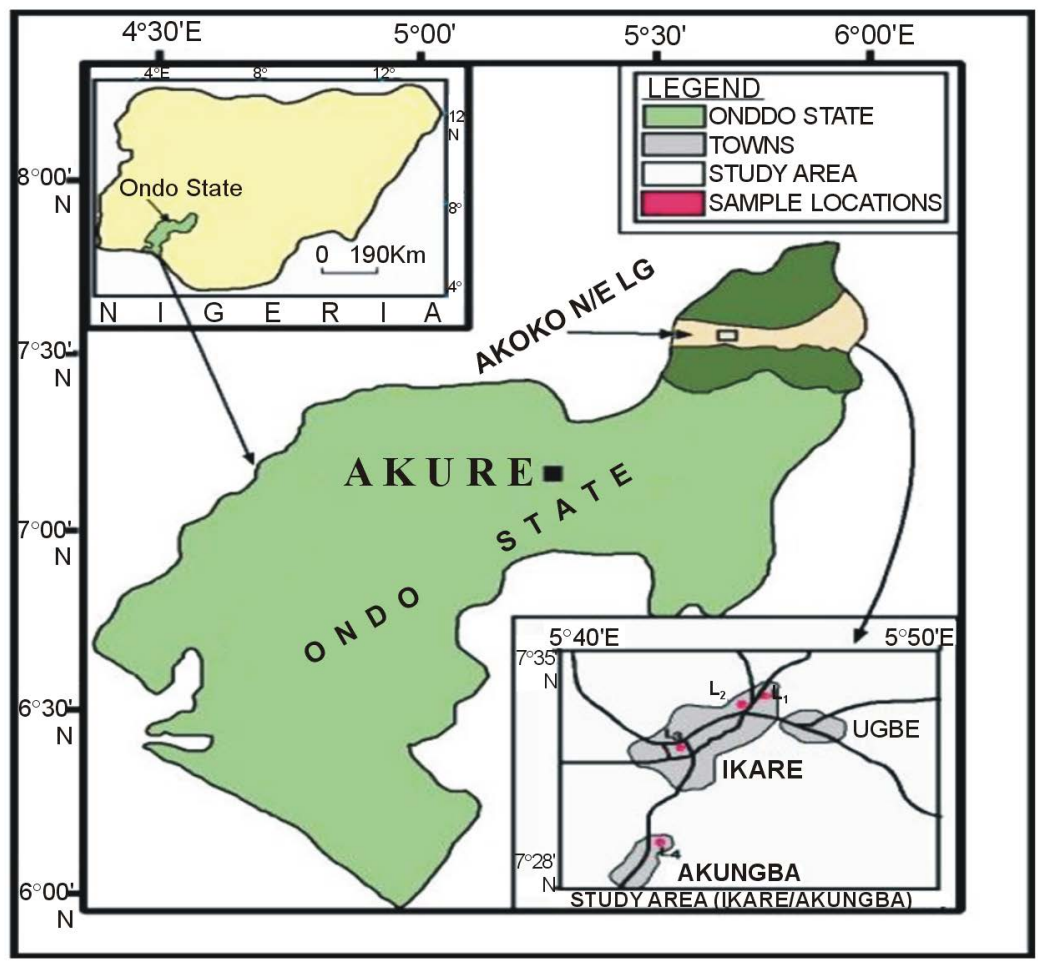

Figure 1. Map of the sampling locations (inserted is the area map of Nigeria and Ondo State showing the geographical locations). 


\subsection{Quality Assurance (QA)/Control (QC)}

Quality assurance (QA)/control (QC) protocol prescribed by the U. S Environmental Protection Agency (EPA) for metal analysis was used. In order to control the analytical procedure, precision of the analytical results was estimated by replicate analysis. All laboratory equipments used for analysis were from Pyrex, washed with $0.1 \mathrm{~N}$ $\mathrm{HNO}_{3}$, rinsed twice with distilled water and placed in a clean environment until dry. All reagents used were of analytical grade (BDH, Merk). Certified standard solutions $1000 \mu \mathrm{g} \cdot \mathrm{g}^{-1}$ (BDH, Ltd.) of elements Pb, Cd, Cu, Cr, $\mathrm{Fe}$, Ni, and Zn were used for Flame Atomic Absorption Analysis. In this study, the use of certified standard reference material PACS-2 (heavily contaminated marine sediment available from the Natural Research Council, Canada) was employed. The results are shown in Table 2. The percentage recoveries varied from $84.1 \%$ to 97.4\% for all the metals excluding Fe.

\subsection{Sample Preparation and Analysis}

Soil samples were air-dried, sieved, and analyzed in the laboratory using standard techniques. Particle size composition was obtained by hydrometer method [20]. Soil pH was determined in water and $0.1 \mathrm{M} \mathrm{KCl} \mathrm{solution}$ at 1.2:5 soil/solution ratios. Organic carbon content was found by the modified $\mathrm{K}_{2} \mathrm{Cr}_{2} \mathrm{O}_{7}$ digestion of WalkleyBlack method [21]. The value of organic matter was obtained by multiplying organic carbon by 1.724 . The cation exchange capacity (CEC) was determined by adding the $1 \mathrm{M} \mathrm{KCl}$ extractable acidity to cations $\left(\mathrm{Ca}^{2+}, \mathrm{Mg}^{2+}\right.$, $\mathrm{Na}^{+}, \mathrm{K}^{+}$) exchanged by neutral $1 \mathrm{M} \mathrm{NH}_{4} \mathrm{C}_{2} \mathrm{H}_{3} \mathrm{O}_{2}(\mathrm{pH}$ 7) as described in Barton and Karathanasis [22]. The $\mathrm{K}$ and $\mathrm{Na}$ were measured with flame photometer while the $\mathrm{Mg}$ and $\mathrm{Ca}$ were determined with atomic absorption spectrophotometer. The exchangeable acidity was determined by titration and the cation exchange capacity (CEC) was obtained by summation of exchangeable cations and exchange acidity.

For the total metals, a $0.5 \mathrm{~g}$ aliquot of the dried powder soil was taken into a $140 \mathrm{ml}$ Teflon bomb and digested in $15 \mathrm{ml}$ of a high purity concentrated $7 \mathrm{ml}-\mathrm{HF}+5 \mathrm{ml}-\mathrm{HNO}_{3}+3 \mathrm{ml}-\mathrm{HCl}$ acid mixture on a hot plate at about $110^{\circ} \mathrm{C}$ for 6 hours within a fume cupboard. After cooling to room temperature, the digest was diluted to $100 \mathrm{ml}$ and dried and then again dissolved in $10 \% \mathrm{HNO}_{3}$ and made up to $20 \mathrm{ml}$ by adding deionized water. Blank samples for soil were prepared. Each preparation of sample was repeated in triplicate.

\subsection{Instrumentation}

The determinations of the heavy metals $\mathrm{Cd}$, Co, Cr, Pb, Fe, Ni and $\mathrm{Zn}$ ) were performed with from the final solution with the use of Alpha 4AAS, Chemical Tech. Analytical Euro model atomic absorption spectrophotometer. The instrument's setting and operational conditions were done in accordance with the manufacturer's specifications. The instrument was calibrated with analytical grade metal standard stock solutions $\left(1 \mathrm{mg} \cdot \mathrm{dm}^{-3}\right) \mathrm{in} \mathrm{tripli-}^{-}$ cate.

\subsection{Statistical Analysis}

We performed statistical analysis by using the raw data. Relationships between metals and other controlling factors were determined by bivariate correlation using the Pearson coefficient in a two-tailed test $(r<0.01$ and 0.05). All analysis was performed using SPSS software (version 13.0).

\section{Results and Discussion}

\section{Results}

Table 3 shows the mean values and standard deviations of $\mathrm{pH}$, organic matter (\%), exchangeable cations $\left(\mu \mathrm{g} \cdot \mathrm{g}^{-1}\right)$, and particle size distribution (i.e. percentages of sand, silt and clay) in soil samples from the areas

\section{Table 2. Results of QA/QC analysis using PACS-2 SRM ${ }^{\mathrm{a}}$ (Trace Metals $\left(\mu \mathrm{g} \cdot \mathrm{g}^{-1}\right)$ dry weight basis).}

\begin{tabular}{cccccc}
\hline Sample & $\mathrm{Cd}$ & $\mathrm{Fe}$ & $\mathrm{Cu}$ & $\mathrm{Pb}$ & 310 \\
Certified-V & 1.000 & $\mathrm{NI}$ & 364 & 183 \\
Measured-V \% Recovery & $0.841(0.11)$ & - & $302(14)$ & $169(8)$ & $342(18)$ \\
\hline
\end{tabular}

*The values in parentheses are standard deviations (SD); MDL = Method detection limit; SRM = Standard reference material; NI = Not indicated; a = Mean of triplicate analysis, $\mathrm{V}=$ Values. 
Table 3. Chemical composition (Mean \pm S.D, $n=9$ ) of soil samples.

\begin{tabular}{cccccc}
\hline Specifications & Soil Depth $(\mathrm{cm})$ & Soil 1 & Soil 2 & Soil 3 & Control \\
\hline $\mathrm{pH}\left(\mathrm{H}_{2} \mathrm{O}\right) 1.2: 5$ & $0-15$ & $7.1 \pm 0.2$ & $6.9 \pm 0.1$ & $6.5 \pm 0.2$ & $6.7 \pm 0.1$ \\
& $15-30$ & $6.7 \pm 0.1$ & $6.7 \pm 0.1$ & $6.4 \pm 0.1$ & $5.7 \pm 0.1$ \\
& $30-45$ & $5.6 \pm 0.2$ & $6.6 \pm 0.2$ & $6.2 \pm 0.2$ & $5.7 \pm 0.1$ \\
$\mathrm{RH}$ & & 61.4 & 56.5 & 58.3 & 59.0 \\
OC (\%) & $0-15$ & $1.74 \pm 0.10$ & $1.57 \pm 0.12$ & $1.22 \pm 0.12$ & $4.18 \pm 0.13$ \\
& $15-30$ & $1.63 \pm 0.21$ & $0.75 \pm 0.24$ & $0.17 \pm 0.16$ & $3.08 \pm 0.20$ \\
$\mathrm{CEC}\left(\mathrm{cmol} \cdot \mathrm{kg}^{-1}\right)$ & $30-45$ & $0.75 \pm 0.11$ & $0.41 \pm 0.13$ & $0.12 \pm 0.11$ & $2.61 \pm 0.11$ \\
& $0-15$ & $10.7 \pm 1.3$ & $9.7 \pm 1.9$ & $9.9 \pm 1.9$ & $15.2 \pm 0.2$ \\
& $15-30$ & $8 . .8 \pm 1.0$ & $7.1 \pm 1.2$ & $5.2 \pm 0.8$ & $12.3 \pm 0.1$ \\
PSD & $30-45$ & $6.7 \pm 1.3$ & $6.6 \pm 1.2$ & $3.3 \pm 0.8$ & $10.5 \pm 0.1$ \\
& Sand (\%) & $67 \pm 3$ & $63 \pm 3$ & $71 \pm 4$ & $55 \pm 2$ \\
& Clay (\%) & $24 \pm 3$ & $26 \pm 2$ & $22 \pm 3$ & $34 \pm 2$ \\
& Silt (\%) & $09 \pm 2$ & $11 \pm 3$ & $09 \pm 3$ & $11 \pm 2$ \\
& T/C & SCL & SCL & SCL & SCL \\
\hline
\end{tabular}

S.D: standard deviation; T/C: textural class; SCL: sand clay loam; OM: organic matter; EC: electrical conductivity; CEC: cation exchange capacity; PSD: particle size distribution.

under study. The $\mathrm{pH}$ values ranged from 6.3 - $7.4(0-15 \mathrm{~cm}) ; 6.2$ - $6.9(15-30 \mathrm{~cm})$ and 5.1 - $6.7(30-45 \mathrm{~cm})$ while the sub-soils are basically slightly acidic. The relative Humidity (RH) of all soils ranged from 56.5 - 61.4 . The total organic matter (TOM) content in the samples ranged from 1.8\% - 3.3\% (0 - $15 \mathrm{~cm}), 0.3 \%-3.0 \%(15-$ $30 \mathrm{~cm}$ ) and $0.2 \%-1.4 \%\left(30-45 \mathrm{~cm}\right.$ ). Based on total soils examined, the CEC (in cmol $\mathrm{kg}^{-1}$ ) ranged from 9.3 $11.2(0$ - $15 \mathrm{~cm})$; 5.1 - $9.7(15-30 \mathrm{~cm})$ and 2.9 - $7.2(30$ - $45 \mathrm{~cm})$ across all studied soils with decreasing order down the profiles at each sample location. The soil samples show a variable admixture of sand, silt and clay. Results show that sand $(>63 \mu \mathrm{m})$ was the main component of all soil samples, with a mean range from $63 \%$ to $71 \%$. Mean clay contents were in the range of $22 \%$ to $24 \%$ and silt in the range $9 \%$ to $11 \%$.

The distribution pattern of the metal across the various soil profiles is presented in Figure 2 (details in supporting information). Across all the sampling locations and profiles, Fe and Cd showed the highest (476.4 $\left.\mu \mathrm{g} \cdot \mathrm{g}^{-1}\right)$ and least $\left(37.5 \mu \mathrm{g} \cdot \mathrm{g}^{-1}\right)$ mean concentration respectively. In terms of concentration value across the various profiles, the highest mean concentration for Ni $\left(99.2 \mu \mathrm{g} \cdot \mathrm{g}^{-1}\right)$, Cu $\left(399.3 \mu \mathrm{g} \cdot \mathrm{g}^{-1}\right)$, Cr $\left(79.8 \mu \mathrm{g} \cdot \mathrm{g}^{-1}\right)$ and Cd $\left(67.4 \mu \mathrm{g} \cdot \mathrm{g}^{-1}\right)$ were recorded in the top soil $(0-15 \mathrm{~cm}$ depth) with decreasing order down the soil profiles. However, the highest for $\mathrm{Pb}\left(210.1 \mu \mathrm{g} \cdot \mathrm{g}^{-1}\right)$ and $\mathrm{Zn}\left(258.1 \mu \mathrm{g} \cdot \mathrm{g}^{-1}\right)$ were recorded in the $30-45 \mathrm{~cm}$ depth with decreasing order up the soil profile.

\section{Discussion}

\subsection{Soil Characterization}

The data in Table 3 shows that the $\mathrm{pH}$ across the entire study area ranged in a narrow interval. Top soils ( 0 - 15 $\mathrm{cm})$ across the study area suggest slightly acidic to neutral condition while the middle $(15-30 \mathrm{~cm})$ and bottom layers $(30-45 \mathrm{~cm}$ ) suggest slightly acidic soil condition. $\mathrm{pH}$ plays significant role in solute concentration and in sorption and desorption of contaminants in soil [23] [24]. However, based on data in Table 3, the pH levels are very close at each soil layer which may suggest that, all other factors being equal, $\mathrm{pH}$ effects on the metal's bioavailability is insignificant.

The CEC is high in all top soils, followed by the middle soils and least in the bottom soils. The reduction in CEC down the soil profile makes the soil less suitable for tap rooted crops. This reduction in CEC of the studied soil over that of the control is a reflection of nutrient depleting wastes or displacement by toxic metals which are indirectly introduced through indiscriminate disposal of auto mechanic wastes. However, there are no significant mean differences $(p<0.05)$ in levels of CEC obtained at each soil layer from the various sampling locations. Soil-1 seems better enriched with macronutrients (Mg, Ca, Na and K) than the other two sites. 


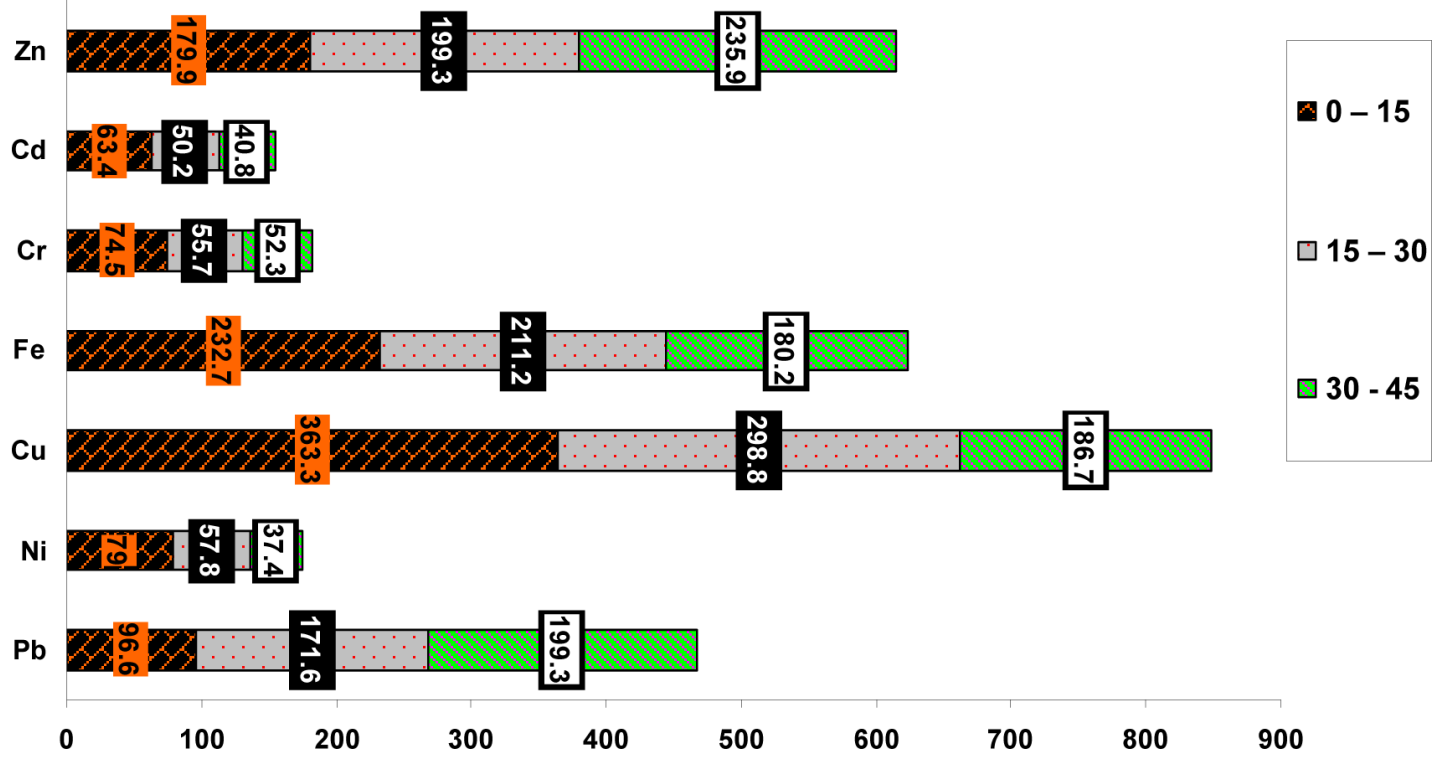

Figure 2. Distribution pattern of the mean concentrations of metals across soil depth (figure is generated from the cumulative data from all sites).

The OM decreases down the soil profile with Soil-1 and Soil-3 displaying the highest and least percentages respectively. The range in organic matter content of the control area $(4.2 \%-7.3 \%)$ is much higher than the range $(0.2 \%-3.3 \%)$ any of the samples from auto-mechanic workshops. The significant difference in the OM content of control and mechanic workshops sample indeed reflects a depletion of this parameter by wastes which are indiscriminately disposed within mechanic workshops. Previous studies have found that higher TOC $(>3.0 \%)$ levels are typically associated with fine soils and lower TOC levels with coarse soils [25].

\subsection{Heavy Metal Distribution}

Metals in soils of the auto-repair workshop are not all retained within the profile depth of 0 - $15 \mathrm{~cm}$ (Figure 2). Average concentrations of $\mathrm{Cd}, \mathrm{Cr}, \mathrm{Cu}, \mathrm{Fe}$ and $\mathrm{Ni}$ obtained from this study generally decreased vertically with soil depth while $\mathrm{Pb}$ and $\mathrm{Zn}$ increased with depth. This illustrates the mobility potential of heavy metals down the soil profile. The study on vertical variations of heavy metals concentrations in soils with depth was able to illustrate potential trends in heavy metals contaminations, which might draw a picture for the historical variations of local contaminations through the temporal analysis on soils. The enhanced concentrations of some of the metals may be attributed to the presence of additives (consisting of metals in various proportions) in lubricants used by auto mechanics.

Slight variation exists between the levels of individual metal across all sampling locations but without any significant mean differences $(\alpha \geq 0.95)$. The variation may be due to factors such as age of the mechanic workshops, volume of work done on each site, types of automobile serviced or repair, type of lubricant commonly used, mode of wastes disposal and type of soil. However, significant variation and mean differences occur between levels of individual metals $(p<0.05)$.

Comparing metal concentrations with Table 1 indicate that apart from Fe (where the DPR value is not indicated) and $\mathrm{Cr}$, all the other metals are well above target values. For metals like cadmium and lead that have no biological function, this calls for public concern [26] [27]. The elevated levels of these metals in the soil profiles constitute a serious threat to both surface and ground water. Some of the metals correlated significantly with percent organic carbon with decreasing soil depth (Figure 3(a) and Figure 3(b)). This is indicative of the significance of organic matter in the sorption of micro pollutants in soil.

The total metal concentrations in the present study were compared to other studies, particularly in Nigeria. As noted earlier, the very few studies were based on top $0-15 \mathrm{~cm}$ soil depth. Apart from $\mathrm{Pb}$ which was found within the range reported [17], mean concentrations of all the other metals were above levels recorded in literature [3] [28]. 


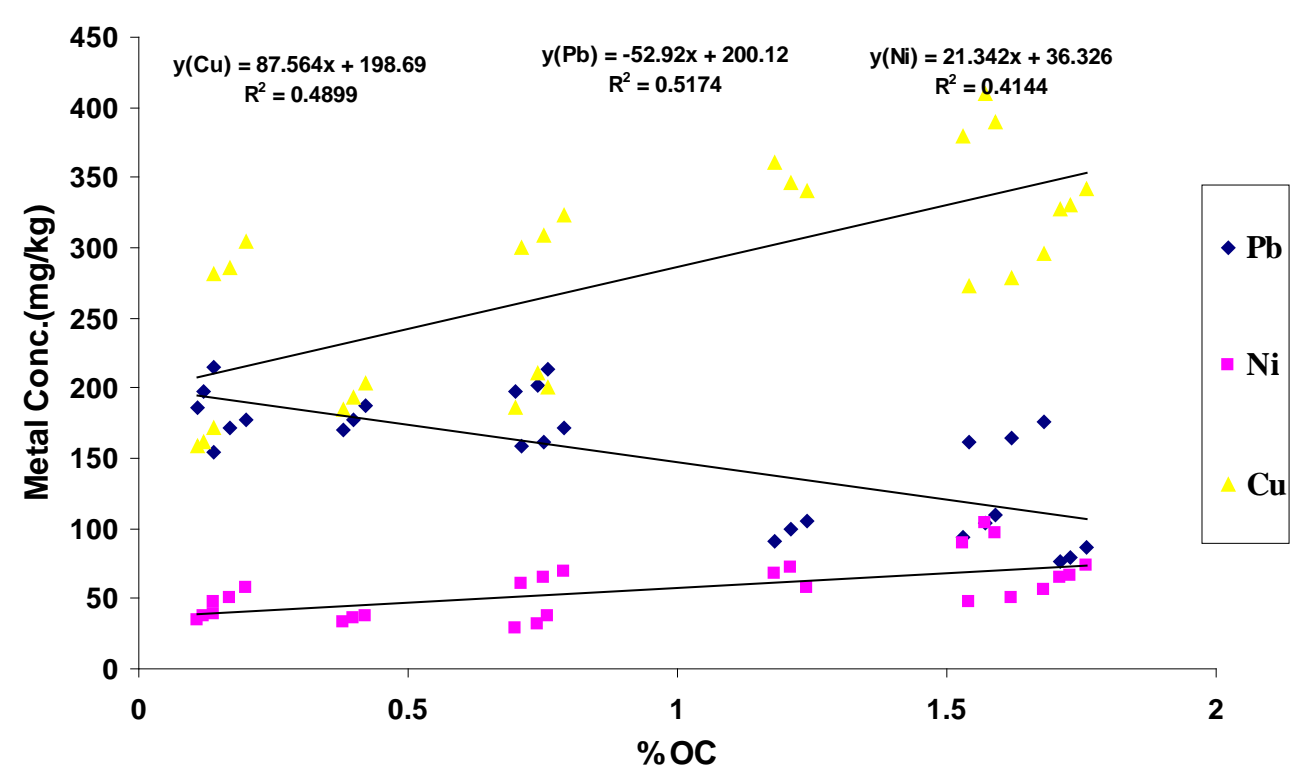

(a)

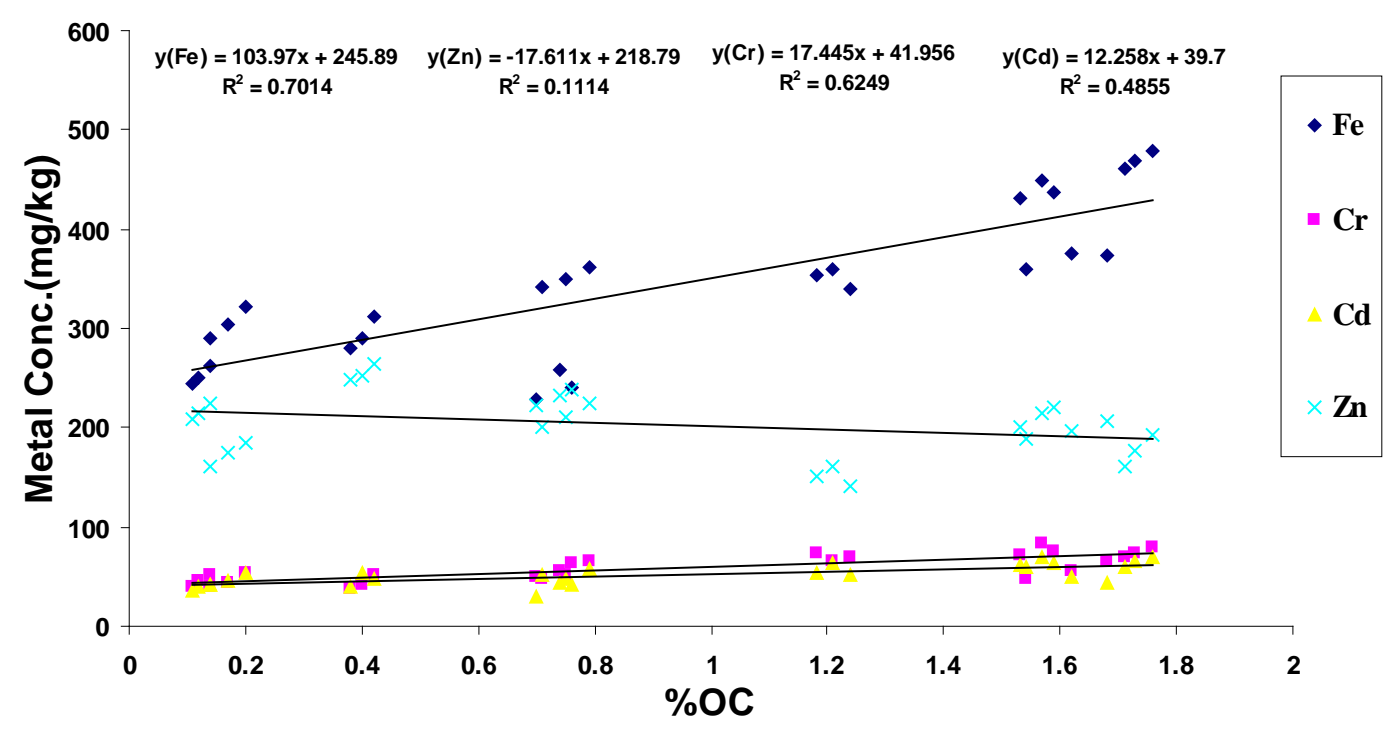

(b)

Figure 3. (a) Correlation graph showing relationship between metal concentration $(\mathrm{Cu}, \mathrm{Pb}$ and $\mathrm{Ni})$ and $\mathrm{OC}$ with decreasing soil depth (figure is generated from the cumulative data from all sites); (b) Correlation graph showing relationship between metal concentration (Fe, $\mathrm{Zn}, \mathrm{Cr}$ and $\mathrm{Cd}$ ) and $\mathrm{OC}$ with decreasing soil depth (figure is generated from the cumulative data from all sites).

\subsection{Indices of Pollution}

In this study, the enrichment factor (EF), contamination factor (CF) and pollution load index (PLI) was applied to assess heavy metal contamination in soil located within automechanic workshops.

\subsubsection{Pollution Load Index (PLI)}

In order to give proper assessment of the degree of contamination, attempts were made to calculate the PLI using the Tomlinson's approach [9]. The PLI represents the number of times by which the metal content in the soil exceeds the average natural background concentration, and gives a summative indication of the overall level of heavy metal toxicity in a particular sample. The control samples were taken to represent natural background. According to Angula [29], PLI is able to give an estimate the metal contamination status and the necessary ac- 
tion that should be taken. The PLI is obtained as a contamination factor (CF) of each metal with respect to the natural background value in the soil [29] [30] by using Equations (1) and (2);

$$
\begin{gathered}
\mathrm{CF}=\mathrm{C}_{\text {sample }} / \mathrm{C}_{\text {background }} \\
\mathrm{PLI}=\left[\mathrm{CF}_{1} \times \mathrm{CF}_{2} \times \mathrm{CF}_{3} \times \cdots \times \mathrm{CF}_{\mathrm{n}}\right]^{1 / \mathrm{n}}
\end{gathered}
$$

where,

CF: contamination factor, $\mathrm{n}=$ number of metals $=7$;

$\mathrm{C}_{\text {sample: }}$ : mean metal concentrate on in polluted soils;

$\mathrm{C}_{\text {background: }}$ mean natural background value of that metal.

In the study, the contamination factor and pollution load index are presented in Table 4. The CFs for the seven metals in the different soil layers are indeed very high ranging from $1.38(\mathrm{Fe})$ to $67.50(\mathrm{Ni})$. The trend is such that highest CFs was observed in $\mathrm{Ni}$ and $\mathrm{Cd}$ and least in Fe. In general, the increasing order of $\mathrm{CFs}$ is $\mathrm{Fe}<\mathrm{Cu}<$ $\mathrm{Zn}<\mathrm{Ni}<\mathrm{Cr}<\mathrm{Pb}<\mathrm{Cd}$. The CFs values decreases down the soil profile in $\mathrm{Ni}$, Fe and $\mathrm{Cu}$ but increases down the soil profile in $\mathrm{Pb}, \mathrm{Cr}$ and $\mathrm{Cd}$. The pattern in $\mathrm{Zn}$ is undefined. The very high values of the CFs (>1) in all the metals can be due to influence of mechanic activities such as indiscriminate disposal of metal containing compounds such as used engine oil, vehicle spare parts, welding activities etc. The data on PLI of all the soil samples (Table 3) were far greater than unity $(>>1)$. Consequently, soils from the mechanic workshops (as representatives of other workshops) are considered to be of pollution concern in view of indiscriminate disposal of used oils, vehicle spare parts and other wastes from their workshops.

\begin{tabular}{|c|c|c|c|c|c|}
\hline Element & Soil Layers & Soil 1 & Soil 2 & Soil 3 & $\begin{array}{l}\text { Natural Background } \\
\text { Concentration }^{\mathrm{a}}\end{array}$ \\
\hline \multirow[t]{3}{*}{$\mathrm{Pb}$} & $0-15$ & 8.36 & 10.31 & 10.02 & $10.1 \pm 0.2$ \\
\hline & $15-30$ & 16.46 & 16.07 & 16.98 & $10.4 \pm 0.6$ \\
\hline & $30-45$ & 17.96 & 15.50 & 26.19 & $11.7 \pm 0.3$ \\
\hline \multirow[t]{3}{*}{$\mathrm{Ni}$} & $0-15$ & 48.85 & 67.50 & 45.01 & $14.7 \pm 1.1$ \\
\hline & $15-30$ & 17.01 & 20.36 & 17.59 & $13.4 \pm 1.4$ \\
\hline & $30-45$ & 14.14 & 16.38 & 14.96 & $10.2 \pm 1.2$ \\
\hline \multirow[t]{3}{*}{$\mathrm{Fe}$} & $0-15$ & 2.05 & 1.90 & 1.50 & $232.7 \pm 8.4$ \\
\hline & $15-30$ & 1.74 & 1.68 & 1.47 & $211.2 \pm 8.9$ \\
\hline & $30-45$ & 1.38 & 1.65 & 1.41 & $180.2 \pm 9.7$ \\
\hline \multirow[t]{3}{*}{$\mathrm{Cu}$} & $0-15$ & 2.56 & 3.05 & 2.70 & $131.1 \pm 6.3$ \\
\hline & $15-30$ & 2.31 & 2.52 & 2.40 & $124.6 \pm 4.0$ \\
\hline & $30-45$ & 1.68 & 1.63 & 1.36 & $120.1 \pm 4.4$ \\
\hline \multirow[t]{3}{*}{$\mathrm{Cr}$} & $0-15$ & 8.05 & 8.59 & 7.43 & $9.3 \pm 0.4$ \\
\hline & $15-30$ & 8.31 & 8.35 & 6.77 & $7.1 \pm 0.4$ \\
\hline & $30-45$ & 19.01 & 15.00 & 14.54 & $3.2 \pm 0.2$ \\
\hline \multirow[t]{3}{*}{ Cd } & $0-15$ & 29.68 & 30.64 & 26.18 & $2.2 \pm 0.2$ \\
\hline & $15-30$ & 44.82 & 48.91 & 43.18 & $1.1 \pm 0.1$ \\
\hline & $30-45$ & 53.57 & 64.71 & 56.71 & $0.7 \pm 0.2$ \\
\hline \multirow[t]{3}{*}{$\mathrm{Zn}$} & $0-15$ & 2.64 & 3.07 & 2.20 & $68.2 \pm 4.3$ \\
\hline & $15-30$ & 2.63 & 2.80 & 2.28 & $77.5 \pm 4.7$ \\
\hline & $30-45$ & 2.82 & 3.14 & 2.63 & $82.3 \pm 5.3$ \\
\hline \multirow[t]{3}{*}{ PLI } & $0-15$ & 5.41 & 6.13 & 5.00 & \\
\hline & $15-30$ & 5.92 & 6.29 & 5.54 & \\
\hline & $30-45$ & 6.32 & 6.43 & 6.26 & \\
\hline
\end{tabular}

Table 4. Elemental contamination factors (CFs) of soils and Pollution Load index (PLI) of metals in different soil layers.

${ }^{\mathrm{a}}$ Average natural background concentration $( \pm \mathrm{SD}, \mathrm{n}=3$ ) obtained in the study. 


\subsubsection{Enrichment Factor and Index of Geo-Accumulation}

The extent of soils contamination was assessed using the enrichment factor (EF) and geoaccumulation index $\left(I_{\text {geo }}\right)$ [11]-[13]. EF was used in the study to assess the relative contributions of natural and anthropogenic heavy metal inputs to soils [31] [32]. It (EF) has also been used to indicate the degree of pollution or contamination or both [33]. Data from samples taken from the control site (University Campus) were used to establish metal-normalizer relationships to which the data generated from various mechanic workshops are compared. According to this technique metal concentrations were normalized to the textural characteristic of soils. Most commonly used reference elements include Sc, $\mathrm{Mn}, \mathrm{Al}$ and $\mathrm{Fe}$ [34]. In this study, Fe was chosen as the geochemical normalizer because of its conservative nature during diagenesis [35]. Moreover, soils in Nigeria have been reported to be rich in Fe [36] [37]. Based on Rubio et al. [38], EF is defined as:

$$
\mathrm{EF}=(\mathrm{X} / \mathrm{Fe})_{\text {soil }} /(\mathrm{X} / \mathrm{Fe})_{\text {background }}
$$

where $(\mathrm{X} / \mathrm{Fe})_{\text {soil }}$ is the ratio of heavy metal $(\mathrm{X})$ to $\mathrm{Fe}$ in the soil from mechanic workshops, and $(\mathrm{X} / \mathrm{Fe})_{\text {background }}$ is the natural background value of the metal-Fe ratio. The EF values close to unity indicate crusted origin, those less than 1.0 suggest a possible mobilization or depletion of metals, whereas EF $>1.0$ indicates that the element is of anthropogenic origin [39]. Five contamination categories are recognized and interpreted as suggested by Birth [40]: $\mathrm{EF}<1$ indicates no enrichment, $\mathrm{EF}<3$ is minor enrichment, $\mathrm{EF}=3-5$ is moderate enrichment, $\mathrm{EF}=5-10$ is moderately severe enrichment, $\mathrm{EF}=10-25$ is severe enrichment, $\mathrm{EF}=25$ 50 is very severe enrichment and EF $>50$ is extremely severe enrichment. Details of the EF values of the metals studied with respect to the natural background concentration are presented in Table 5. Variation occurs in the $\mathrm{EFs}$ with $\mathrm{Pb}, \mathrm{Cd}$ and $\mathrm{Ni}$ occurring at levels $\geq 9$ while $\mathrm{Cu}, \mathrm{Cr}$ and $\mathrm{Zn}$ occur at values $<1.0$. Thus, based on Birth [40] interpretation, the EFs for $\mathrm{Cu}, \mathrm{Cr}$ and $\mathrm{Zn}$ indicated no enrichment which suggested a possible mobilization of metals while all the auto-mechanic workshops are said to be severely enriched with $\mathrm{Pb}, \mathrm{Cd}$ and $\mathrm{Ni}$. Do these truly represent anthropogenic input? In a recent report, it has been shown that high EFs do not provide a reliable indication of the degree of human interference with the global environment [41]. In the report carried out in Czech Republic where five different elements were used as reference, the sequence of the EFs does not reflect the relative importance of the elements determined. It was concluded that other factors such as the choice of reference element may be responsible for high EFs. The variation in EFs from site to site may also reflect the age of establishment of the various workshops and indicative of the number of services each workshops render.

Table 5. Mean $\mathrm{EF}^{*}$ and $I_{\mathrm{geo}}{ }^{*}$ classes of the metals studied with respect to the natural background.

\begin{tabular}{|c|c|c|c|}
\hline Element & Soil 1 & Soil 2 & Soil 3 \\
\hline \multicolumn{4}{|c|}{ Enrichment Factor } \\
\hline $\mathrm{Pb}$ & 8.85 & 9.72 & 13.41 \\
\hline $\mathrm{Ni}$ & 17.31 & 25.73 & 20.20 \\
\hline $\mathrm{Cu}$ & 0.11 & 0.14 & 0.15 \\
\hline $\mathrm{Cr}$ & 0.35 & 0.40 & 0.44 \\
\hline $\mathrm{Cd}$ & 10.24 & 11.36 & 12.33 \\
\hline $\mathrm{Zn}$ & 0.20 & 0.47 & 0.23 \\
\hline \multicolumn{4}{|l|}{$I_{\text {geo }}$ class $^{\mathrm{a}}$} \\
\hline $\mathrm{Pb}$ & 1.01 & 1.02 & 1.11 \\
\hline $\mathrm{Ni}$ & 1.28 & 1.40 & 1.26 \\
\hline $\mathrm{Cu}$ & 1.71 & 0.31 & 0.25 \\
\hline $\mathrm{Cr}$ & 0.73 & 0.76 & 0.69 \\
\hline $\mathrm{Cd}$ & 1.30 & 1.31 & 1.24 \\
\hline $\mathrm{Zn}$ & 0.49 & 0.56 & 0.41 \\
\hline
\end{tabular}

${ }^{*}$ Values calculated based on soil layer $0-15 \mathrm{~cm}$ only. Normalizing element, Fe, with natural background value of $232.7 \mu \mathrm{g} \cdot \mathrm{g}^{-1}$. a $>5$, extremely contaminated; 4 - 5, strongly to extremely strongly contaminated; $3-4$, strongly contaminated; 2 - 3, moderately to strongly contaminated; 1 - 2, moderately contaminated; 0 - 1, uncontaminated to moderately contaminated; <0, practically uncontaminated (Muller, 1979; Forstner et al., 1993). 


\subsubsection{Geoaccumulation Index}

The geoaccumulation index $\left(I_{\text {geo }}\right)$ as defined by Equation (4) was used to quantify the extent of heavy metal contamination associating with the soils from the various mechanic workshops. The $I_{\text {geo }}$ values were calculated using the Muller's [41] expression:

$$
I_{\text {geo }}=\log _{2} C_{m} / 1.5 B_{n}
$$

where $C_{m}=$ measured total concentration of metals in soils $\left(\mu \mathrm{g} \cdot \mathrm{g}^{-1}\right) ; B_{n}=$ geochemical background values of metals $\left(\mu \mathrm{g} \cdot \mathrm{g}^{-1}\right) ; 1.5=$ the background matrix correction factor due to lithogenic effects. The $I_{\text {geo }}$ scale consists of seven grades $(0-6)$ ranging from uncontaminated to very highly contaminated (Table 5). The results of the $I_{\text {geo }}$ of the metals investigated in the study are presented in Table 4. Unlike the EFs, the $I_{\text {geo }}$ values are generally low $(<2)$ in all cases. In all the soils, the six metals fall within two $I_{\text {geo }}$ class based on Muller's [41] interpretation; moderate contamination $(\mathrm{Pb}, \mathrm{Cd}$ and $\mathrm{Ni}$ ) and uncontaminated to moderate contamination $(\mathrm{Cu}, \mathrm{Cr}$ and $\mathrm{Zn})$. This contamination can only result from anthropogenic activities considered to emanate from mechanic activities.

\subsection{Correlation Matrix}

The results of correlation between the various metals (Table 6) were calculated using the entire raw data. This was aimed at reducing possible bias that might result from mean values. The correlation coefficient data is important in order to deduce the possible sources of the metals in the soil samples. Based on the data in Table 5, the concentrations of several metals were strongly correlated with each other. Major correlations in soils were between $\mathrm{Cu}-\mathrm{Ni}$, Cu-Fe, Fe-Ni, Cd-(Ni, Fe and $\mathrm{Cu})(r \geq 0.95 ; p<0.05 ; d f=20)$. Other correlations between $\mathrm{Cd}$-(Pb, $\mathrm{Cr})$ and $\mathrm{Cr}-\mathrm{Cu}(r \geq 0.99 ; p<0.01 ; d f=20)$ were also obtained along with a strongly negative correlation between Fe-Pb $(r \geq 0.95 ; p<0.05 ; d f=20)$. The correlation coefficients between the concentrations of the different metals indicate strong links between them, which probably reflects their related origin. The wastes which are indiscriminately disposed within the various workshops are possible sources of these metals.

\section{Conclusion}

This survey has allowed the determination of the level of some important heavy metals at different layers of the soil. The combined use of different approaches for evaluating soil metal contamination facilitates a comprehensive interpretation of the soil characteristics in terms of the background influences. The mechanic environment is getting polluted particularly with $\mathrm{Pb}, \mathrm{Ni}$ and $\mathrm{Cd}$ based on the enrichment factor. This is a reflection of anthropogenic contribution which might partly result from the use of metal-containing additives as lubricants. Based on the geoaccumulation index data, the soils can generally be classified as "moderately contaminated" by these heavy metals although the pollution index load indicate that the entire mechanic soils are considered to be of pollution concern. There was an indication of an uneven distribution of the metals in soils from various locations, though there was no significant difference in metal distributions between them.

\section{Recommendations and Perspectives}

This study assessed the extent of heavy-metal contamination in soils within auto mechanic workshops using some pollution indexes. Consequent upon our findings, it is recommended that government should provide appropriate places that will serve as automobile village where auto repairs are being carried out. This may not be

Table 6. Correlation matrix of metals.

\begin{tabular}{|c|c|c|c|c|c|c|}
\hline $\mathrm{Pb}$ & $\mathrm{Ni}$ & $\mathrm{Fe}$ & $\mathrm{Cu}$ & $\mathrm{Cr}$ & $\mathrm{Cd}$ & $\mathrm{Zn}$ \\
\hline \multirow[t]{7}{*}{1.000} & $-0.771^{*}$ & $-0.853^{* *}$ & $-0.827^{* *}$ & $-0.755^{*}$ & $0.789^{*}$ & 0.628 \\
\hline & 1.000 & $0.840^{* *}$ & $0.936^{* *}$ & $0.774^{*}$ & $0.818^{* *}$ & 0.359 \\
\hline & & 1.000 & $0.844^{* *}$ & $0.757^{*}$ & $0.884^{* *}$ & 0.382 \\
\hline & & & 1.000 & $0.762^{*}$ & $0.805^{* *}$ & -0.566 \\
\hline & & & & 1.000 & $0.716^{*}$ & 0.313 \\
\hline & & & & & 1.000 & -0.315 \\
\hline & & & & & & 1.000 \\
\hline
\end{tabular}

Significant $/ \mathrm{r} /{ }^{*}(p<0.05) ;{ }^{* *}(p<0.01)$. 
necessary in developed countries where measures are already put in place as appropriate. Education and legislation on management of wastes in the auto-mechanic workshops should be intensified to forestall the effects of waste oil related problems on the environment, particularly on groundwater. Also, modern waste disposal facilities should be acquired by relevant authorities and appropriate waste disposal sites be chosen to avoid the injurious effects of indiscriminate disposal of used oils/lubricants. In addition, continuous monitoring and further studies on the level of these heavy metals should be carried out in the near future to ascertain long-term effects of anthropogenic impact. This should also involve larger coverage with studies on ground water around such locations. In addition, metals speciation should be carried out so that the form and extent of metal bioavailability can be evaluated further.

\section{References}

[1] European Environment Agency, EEA (2007) Progress in Management of Contaminated Sites (CSI 015). EEA. Assessment Published July 2005; Kongen, ytorv, 6 DK-1050, Denmark. http://www.eea.europa.eu

[2] United States Department of Agriculture (2001) Natural Resources Conservation Services, Soils Quality Institute, Urban Technical Note.

[3] Adeniyi, A.A. and Afolabi, J.A. (2002) Determination of Total Petroleum Hydrocarbons and Heavy Metals in Soils within the Vicinity of Facilities Handling Refined Petroleum Products in Lagos Metropolis. Environ International, 28, 79-82. http://dx.doi.org/10.1016/S0160-4120(02)00007-7

[4] Lim, H., Lee. J., Chon, H. and Sager, M. (2008) Heavy Metal Contamination and Health Risk Assessment in the Vicinity of the Abandoned Songcheon Au-Ag Mine in Korea. Journal of Geochemical Exploration, 96, 223-230. http://dx.doi.org/10.1016/j.gexplo.2007.04.008

[5] Sharma, H.D. and Reddy, K.R. (2004) Geo-Environmental Engineering: Site Remediation, Waste Containment and Emerging Waste Management Technologies, John Wiley, New Jersey.

[6] Zwolsman, I.G.J., Berger, W.G. and Vaneck, M.T.G. (1993) Sediment Accumulation Rates, Historical Input, Post Depositional Mobility and Retention of Major Elements and Trace Metals in Salt Marsh Sediments of the Scheldt Estuary, SW Netherlands. Marine Chemistry, 44, 73-94. http://dx.doi.org/10.1016/0304-4203(93)90007-B

[7] Loring, H.D. and Rantala, R. (1992) Manual for the Geochemical Analyses of Marine Sediments and Suspended Particulate Matter. Earth-Science Review, 32, 235-283. http://dx.doi.org/10.1016/0012-8252(92)90001-A

[8] Niencheskil, L.F.H., Windom, L.H. and Smith, R. (1994) Distribution of Particulate Trace Metal in Patos Lagoon Estuary (Brazil). Marine Pollution Bulletin, 28, 96-102. http://dx.doi.org/10.1016/0025-326X(94)90545-2

[9] Tomllinson, D.C., Wilson, J.G., Harris, C.R. and Jeffrey, D.W. (1980) Problems in the Assessment of Heavy Metals Levels in Estuaries and The formation of Pollution Index. Helgoländer Wissenschaftliche Meeresuntersuchungen, 33, 566-569. http://dx.doi.org/10.1007/BF02414780

[10] Aloupi, M. and Angelidis, M.O. (2001) Geochemistry of Natural and Anthropogenic Metals in the Coastal Sediments of the Island of Lesvos, Aegean Sea. Environmental Pollution, 113, 211-219. http://dx.doi.org/10.1016/S0269-7491(00)00173-1

[11] Woitke, P., Wellmitz, J., Helm, D., Kube, P., Lepom, P. and Litheraty, P. (2003) Analysis and Assessment of Heavy Metal Pollution in Suspended Solids and Sediments of the River Danube. Chemosphere, 51, 633-642. http://dx.doi.org/10.1016/S0045-6535(03)00217-0

[12] Reddy, M.S., Basha, S., Kumar, V.G.S., Joshi, H.V. and Ramachandraiah, G. (2004) Distribution, Enrichment and Accumulation of Heavy Metals in Coastal Sediments of Alang-Sosiya Ship Scrapping Yard, India. Marine Pollution Bulletin, 48, 1055-1059. http://dx.doi.org/10.1016/j.marpolbul.2003.12.011

[13] Selvaraj, K., Mohan, V.R. and Szefer, P. (2004) Evaluation of Metal Contamination in Coastal Sediments of the Bay of Bengal, India: Geochemical and Statistical Approaches. Marine Pollution Bulletin, 49, 174-185. http://dx.doi.org/10.1016/j.marpolbul.2004.02.006

[14] Department of Petroleum Resources, DPR (1991) Environmental, Guidelines and Standards for the Petroleum Industry in Nigeria.

[15] Kabata-Pendas, A. (1995) Agricultural Problems Related to Excessive Trace Metal Contents of Soil. In: Salomons, W., Forstner, U. and Mader, P., Eds., Heavy Metals (Problems and Solutions), Springer Verlag, Berlin, Heidelberg, New York, London, Tokyo, 3-18.

[16] Onianwa, P.C. (1995) Petroleum Hydrocarbon Pollution of Urban Top Soil in Ibadan City, Nigeria. Environment International, 21, 341-343. http://dx.doi.org/10.1016/0160-4120(95)00018-G

[17] Fakayode, S.O. and Olu-Owolabi, B.I. (2003) Heavy Metal Contamination of Roadside Topsoil in Osogbo, Nigeria: Its 
Relationship to Traffic Density and Proximity to Highways. Environmental Geology, 44, 150-157.

[18] Liu, Y.G., Wang, X.H., Zeng, G.M., Li, X., Zhou, C.H., Fan, T., et al. (2006) Redistribution of Pb, Zn and Cu Fractions in Tailing Soils Treated with Different Extractants. Pedosphere, 16, 312-318. http://dx.doi.org/10.1016/S1002-0160(06)60057-X

[19] Boulding, J.R. (1994) Description and Sampling of Contaminated Soils (A Field Guide). 2nd Edition, Lewis Publisher, Boca Raton.

[20] Bouyoucos, G.J. (1927) The Hydrometer as a New Method for the Mechanical Analysis of Soils. Soil Science, 23, 343353. http://dx.doi.org/10.1097/00010694-192705000-00002

[21] Nelson, P.W. and Sommers, C.E. (1982) Total Carbon, Organic Carbon and Organic Matter. In: Page, A.L., Ed., Methods of Soil Analysis, Part 2, SSSA, Madison, 539-579.

[22] Barton, C.D. and Karathanasis, A.D. (1997) Measuring Cation Exchange Capacity and Total Exchangeable Bases in Batch and Flow Experiments. Soil Technology, 11, 153-162. http://dx.doi.org/10.1016/S0933-3630(97)00002-0

[23] Gillman, G.P. (1981) Effect of Ph and Ionic Strength on the Cation Exchange Capacity of Soils with a Variable Charge. Australian Journal of Soil Research, 19, 93-96. http://dx.doi.org/10.1071/SR9810093

[24] Elliot, H.A., Liberati, M.R. and Huang, C.P. (1986) Competitive Adsorption of Heavy Metals by Soils. Journal of Environmental Quality, 15, 214-219. http://dx.doi.org/10.2134/jeq1986.00472425001500030002x

[25] Kamaruzzaman, B.Y., Waznah, A.S., Ong, M.C., Shahbudin, S, and Jalal, K.C.A. (2009) Variability of Organic Carbon Content in Bottom Sediment of Pahang River Estuary, Pahang, Malaysia. Journal of Applied Sciences, 9, 42534257. http://dx.doi.org/10.3923/jas.2009.4253.4257

[26] Tchernitchin, N.N., Villagra, A. and Tchernitchin, A.N. (1998) Antiestrogenic Activity of Lead. Environmental Toxicology and Water Quality, 13, 43-53.

[27] Martinez-Tabche, L., Mora, B.R., Faz, C.G., Castelan, I.G., Ortiz, M.M., Gonzalez, V.U. and Flores, M.O. (1997) Toxic Effect of Sodium Dodecylbenzene-Sulfonate, Lead, Petroleum, and Their Mixtures on the Activity of Acetylcholinesterase of Moinamacrocopa in Vitro. Environmental Toxicologyand Water Quality, 12, 211-215.

[28] Ogunfowokan, A.O., Oyekunle, J.A.O., Durosinmi, L.M., Akinjokun, A.I. and Gabriel, O.D. (2009) Speciation Study of Lead and Manganese in Roadside Dusts from Major Roads in Ile-Ife, South Western Nigeria. Chemistry and Ecology, 25, 405-415. http://dx.doi.org/10.1080/02757540903325112

[29] Angulo, E. (1996) The Tomllinson Pollution Load Index Applied to Heavy Metals “Mussel-Watch” Data: A Useful Index to Assess Coastal Pollution. Science of the Total Environment, 187, 19-56. http://dx.doi.org/10.1016/0048-9697(96)05128-5

[30] Usero, U., Garcia, A. and Fraidias, J. (2000) Calidad de lasaguasysedimentos del LitoralAndaluz. In: Sevilla, Ed., Junta de Andalicia, Consejeria del Medio Ambiente, 164

[31] Adamo, P., Arienzo, M., Imperato, M., Naimo, D., Nardi, G. and Stanzione, D. (2005) Distribution and Partition of Heavy Metals in Surface and Sub-Surface Sediments of Naples City Port. Chemosphere, 61, 800-809. http://dx.doi.org/10.1016/j.chemosphere.2005.04.001

[32] Valdés, J., Vargas, G., Sifeddine, A., Ortlieb, L. and Guiñez, M. (2005) Distribution and Enrichment of Heavy Metals in Mejillones Bay $\left(23^{\circ} \mathrm{S}\right)$, Northern Chile: Geochemical and Statistical Approach. Marine Pollution Bulletin, 50, 15581568.

[33] Feng, H., Han, X., Zhang, W. and Yu, L. (2004) A Preliminary Study of Heavy Metal Contamination in Yangtze River Intertidal Zone Due to Urbanization. Marine Pollution Bulletin, 49, 910-915. http://dx.doi.org/10.1016/j.marpolbul.2004.06.014

[34] Loska, K., Cebula, J., Pelczar, J., Wiechuła, D. and Kwapuliński, J. (1997) Use of Enrichment, and Contamination Factors Together with Geoaccumulation Indexes to Evaluate the Content of $\mathrm{Cd}, \mathrm{Cu}$, and $\mathrm{Ni}$ in the Rybnik Water Reservoir in Poland. Water, Air, and Soil Pollution, 93, 347-365. http://dx.doi.org/10.1007/BF02404766

[35] Chapman, P.M. and Wang, F. (2001) Assessing Sediment Contamination in Estuaries. Environmental Toxicology and Chemistry, 20, 3-22. http://dx.doi.org/10.1002/etc.5620200102

[36] Ololade, I.A., Lajide, L. and Amoo, I.A. (2007) Enrichment of Heavy Metals in Sediments as Pollution Indicator of the Aquatic Ecosystem. Pakistan Journal of Scientific and Industrial Research, 50, 27-35.

[37] Kakulu, S.E. (1985) Heavy Metals in the Niger Delta: Impact of Petroleum Industry on the Baseline Levels. Ph.D. Thesis University of Ibadan, Ibadan.

[38] Rubio, B., Nombela, M.A. and Vilas, F. (2000) Geochemistry of Major and Trace Elements in Sediments of the Ria de Vigo (NW Spain): An Assessment of Metal Pollution. Marine Pollution Bulletin, 40, 968-980. http://dx.doi.org/10.1016/S0025-326X(00)00039-4

[39] Zsefer, P., Glasby, G.P., Sefer, K., Pempkowiak, J. and Kaliszan, R. (1996) Heavy-Metal Pollution in Superficial Sedi- 
ments from the Southern Baltic Sea off Poland. Journal Environmental Science Health, Part A: Environmental Science and Engineering and Toxicology, 31, 2723-2754.

[40] Birth, G.A. (2003) A Scheme for Assessing Human Impacts on Coastal Aquatic Environments Using Sediments. Woodcoffe, C.D. and Furness, R.A., Eds., Coastal GIS 2003, Wollongong University Papers in Centre for Maritime Policy, 14, Wollongong.

[41] Sucharovà, J., Suchara, I, Hola, M., Marikova, S., Reimann, C., Boyd, R., Filzmoser, P. and Englmaier, P. (2012) Top-/Bottom-Soil Ratios and Enrichment Factors: What Do They Really Show? Applied Geochemistry, 27, 138-145. http://dx.doi.org/10.1016/j.apgeochem.2011.09.025 
Scientific Research Publishing (SCIRP) is one of the largest Open Access journal publishers. It is currently publishing more than 200 open access, online, peer-reviewed journals covering a wide range of academic disciplines. SCIRP serves the worldwide academic communities and contributes to the progress and application of science with its publication.

Other selected journals from SCIRP are listed as below. Submit your manuscript to us via either submit@scirp.org or Online Submission Portal.
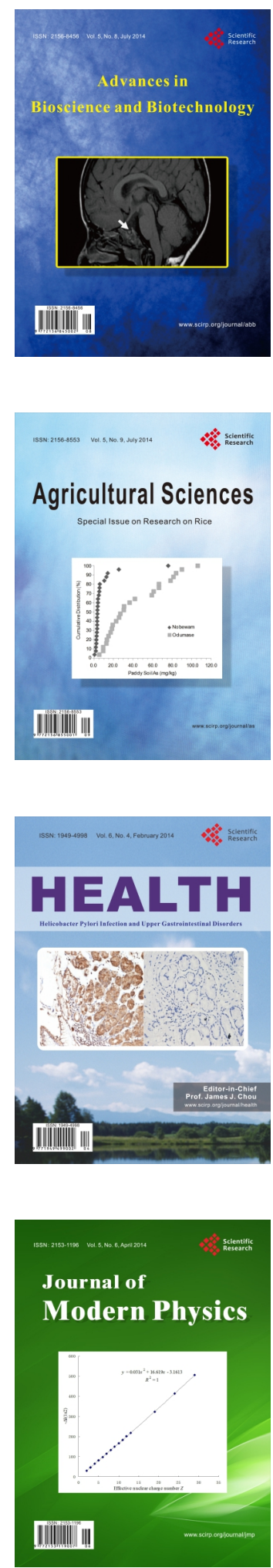
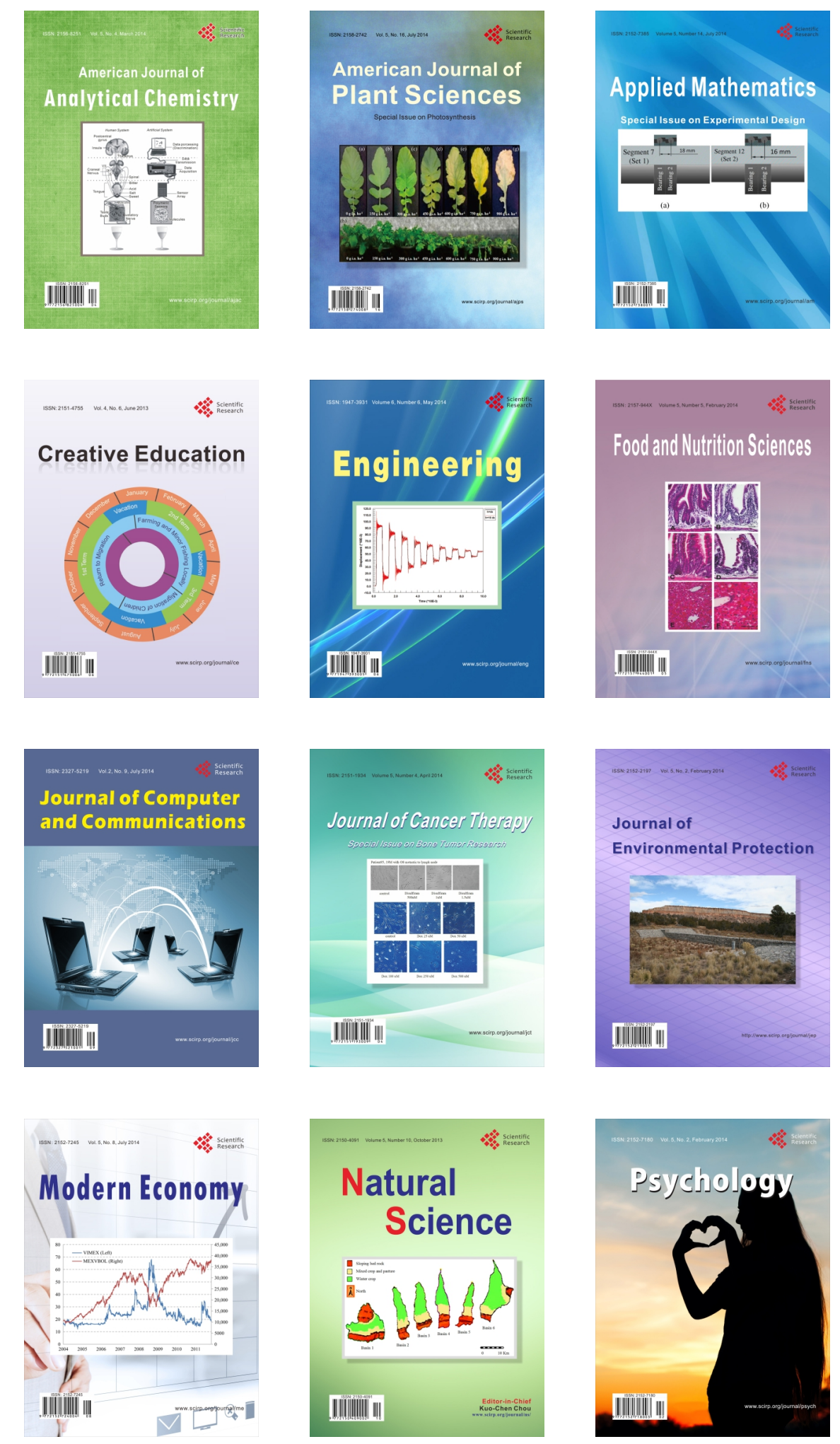